\title{
WHAT KIND OF SYSTEMIC RISKS DO WE FACE \\ IN THE EUROPEAN BANKING SECTOR? \\ THE APPROACH OF COVAR MEASURE
}

Renata Karkowska, Ph.D.

University of Warsaw

Faculty of Management

Szturmowa 1/3, 02-678 Warsaw, Poland

e-mail: rkarkowska@wz.uw.edu.pl

Received 23 September 2014, Accepted 1 December 2014

\begin{abstract}
We measure a systemic risk faced by European banking sectors using the CoVaR measure. We propose the conditional value-at-risk for measuring a spillover risk which demonstrates the bilateral relation between the tail risks of two financial institutions. The aim of the study is to estimate the contribution systemic risk of the bank $i$ in the analyzed banking sector of a country in conditions of its insolvency. The study included commercial banks from 8 emerging markets from Europe, which gave a total of 40 banks, traded on the public market, which provided a market valuation of the bank's capital. The conclusions are that the CoVaR seems to be a better measure for systemic risk in the banking sector than the $\mathrm{VaR}$, which is more individual. And banks in developing countries in Europe do not provide significant risk for the banking sector as a whole. But it must be taken into account that some individuals that may find objectionable. Our results hence tend to a practical use of the CoVaR for supervisory purposes.
\end{abstract}

Keywords: systemic risk, value at risk, risk spillovers, banking sector.

JEL classification: G01, G10, G20, G28, G38. 


\section{Introduction}

During financial crises, losses tend to spread across the financial system more than average. The situation of crises gives rise to systemic risk. We define the systemic risk as the event in which spillovers across financial institutions can arise from liquidity spirals, fire-sales of assets and counterparty credit risk in financial sector. Systemic risk measures try to capture the potential spread of financial distress across sector. As a result, the correlation between the assets and liabilities of financial institutions tends to rise above the level excusably based on fundamental analysis. Therefore, it seems that the measures evaluating systemic risk should capture the potential spread of the difficult financial situation of the institution where deviation from the mean is higher (what is commonly referred to as extreme, "tail" part of the distribution of rates of return).

Recently MES, the so-called Marginal Expected Shortfall, of a financial institution, has been adapted as the systemic risk measurement ${ }^{1}$. The measure is defined as the expected equity loss per sum invested in the institutions if the whole market declines by a certain amount (a "tail event" in the system). In turn, Brownlees and Engle ${ }^{2}$ proposed a multi-step modeling approach based on GARCH, Dynamic Conditional Correlations (DCC). Acharya et al. found that the MES of a large sample of US financial institutions was a good predictor of the total decline in equity valuation of firms experienced during the crisis ${ }^{3}$.

Lastly, the most common measure of risk used by banks is the value at risk (VaR), which estimates the risk of an individual institution. This proposed by the bank JP Morgan focuses mainly on the risks of individual institutions. The value of $\alpha-V a R$ is the maximum loss for a confidence level $\alpha$, in the accepted interval Kupiec ${ }^{4}$ and Jorion ${ }^{5}$. Note, however, that the measure that estimates the risk of a single institution does not necessarily reflect systemic risk or threat to the stability of the financial system as a whole. According to the classification adopted by the Brunnermeier's', Crocket, Goodhart, Perssaud and Shin', a measure of systemic risk should determine the risk of the system by the individual systemically important institutions, which are connected to each other and so large that in case of a crisis may cause negative consequences for the other participants in the system, as well as the institutions that make up the system as a whole - "systemic as part of herd". The group of combined financial institutions that act as clones can be as dangerous to the system, as big systemically important entities Brady $^{7}$, Rubin, Greenspan, Levitt and Born ${ }^{8}$, Brunnermeier ${ }^{9}$ and Adrian and Shin ${ }^{10}$. Second, risk estimates should take into account that the risk usually is the result of speculative bubbles and imbalances of the past, and materializes only in times of crisis. 
Therefore, measures of risk, based on the high frequency data, which are based mainly on the current price movements are potentially confusing them and build regulatory requirements appear to be at risk of pro-cyclicality. The following study aims to present the use of VaR measures for the verification of systemic risk, and the measurement of their value in the banking systems of 8 countries of developing Europe (Bulgaria, Latvia, Lithuania, Poland, Romania, Turkey, Ukraine, Hungary) in the period 2000-2012.

Measuring systemic risk to individual banks and national banking systems will be verified using the CoVaR method. Thus, the estimates will be made conditional on the selected institutions measure and relative to the entire financial system. VaR calculations will apply to the entire financial system, provided that the institution $i$ is in a crisis situation. The aim of the study is to estimate the contribution of systemic risk of the bank $i$ in the analyzed sector of the country, in crisis conditions of bank $i$. The study has adopted the following hypotheses:

1. Evaluation of the banking system, closely based on the principles of valuation of individual financial institutions, i.e. as a static set of assets, ignores interactions arising from systemic risks.

2. Systemic risk is characterized by individualized nature, requiring a separate monitoring and management in each banking sector.

The rest of the paper is organized as follows. In section 2 we describe the CoVaR methodology. In section 3 we present our bank balance-sheet dataset. In section 4, we estimate of the contribution of European banks to the instability of the banking sector. Finally, section 5 concludes.

\section{CoVaR methodology}

For the state of financial failure of a financial institution $\mathrm{X}, \mathrm{VaR}$ at probability level $\mathrm{p}$ is defined by:

$$
P(X>\operatorname{VaR}(p))=p
$$

We can say that the bank is in a crisis situation $X$, which access $\operatorname{VaR}(p)$ with a very low $p$ level.

In order to assess risk-taking by individual institution macro-prudential regulations adopt the level of probability $p$ equal to $1 \%$. However, imposing the same $p$ level restriction dedicated to the definition of banking crises for all banks, may not be the best solution. Due to the fact 
that a uniform level of losses in the definition of a crisis can not fit into a diversified financial situation of individual institutions.

Adrian and Brunnermeier ${ }^{11}$ propose a risk measure based on $V a R$, but with contingencies - CoVaR, where "Co" is an abbreviation of "comovement" (the correlation), "contagion" (contagion effect), "conditional" (conditionality). They focus on the estimates of the conditional measure CoVaR where CoVaR is for selected institution $i$ relative to the entire financial system. Therefore, $V a R$ calculations apply to the entire financial system, provided that the institution $i$ is in a crisis situation.

Risk measure can be defined as the VaR institution $j$ (the entire financial system), provided the incident and crisis institutions. Other words, can be expressed as q-quantile distribution of conditional probability:

$$
\operatorname{Pr}\left(X^{j} \leq \operatorname{CoVaR}_{q}^{j \mid c\left(x^{i}\right)} \mid C\left(X^{i}\right)\right)=q
$$

The contribution of the institution i to the institution's risk $\mathrm{j}$ we denote the change:

$$
\Delta \operatorname{CoVaR}_{q}^{j \mid i}=\operatorname{CoVaR}_{q}^{j \mid X^{i}=\operatorname{VaR}_{q}^{i}}-\operatorname{CoVar}_{q}^{j \mid X^{i}=\text { Median }^{i}}
$$

Adrian and Brunnermeier ${ }^{12}$ in their estimations of measure CoVaR studied the market changes in the value of assets of financial institutions, using the market value of equity and leverage of financial sector institutions, defining the distribution of changes in assets for institutions $i$ at time $t$ as:

where:

$$
X_{t}^{i}=\frac{M E_{t}^{i} \times L E V_{t}^{i}-M E_{t-1}^{i} \times L E V_{t-1}^{i}}{M E_{t-1}^{i} \times L E V_{t-1}^{i}}=\frac{A_{t}^{i}-A_{t-1}^{i}}{A_{t-1}^{i}}
$$

$A_{t}^{i}=M E_{t}^{i} \times L E V_{t}^{i}$, and $A_{t}^{i}=M E_{t}^{i} \times L E V_{t}^{i}=B A_{t}^{i} \times\left(M E_{t}^{i} / B E_{t}^{i}\right)$,

$B A^{i}{ }_{t}$ - book value of assets of institution $i$ in time $t$,

$M E^{i}{ }_{t}$ - market value of equity of institution $i$ in time $t$,

$L E V_{t}^{i}-$ leverage, measure as assets to equity of institution $i$ in time,

$B E_{t}^{i}$ - book value of equity of institution $i$ in time $t$.

In order to estimate the size of CoVaR quantile regression was used for the financial sector due to changes in the rate of return financial institution $i$, for quantile $\mathrm{q}$.

$$
X_{q}^{s y s t e m, i}=\alpha_{q}^{i}+\beta_{q}^{i} X^{i}
$$


Directly using the assumptions of $V a R$ can be determined $V a R_{q}$ for the entire financial system on condition $X_{i}$ as quantile $q$ :

$$
\operatorname{VaR}_{q}^{\text {system }, i} \mid X^{i}=X_{q}^{\text {system }, i}
$$

\section{Financial Institutions Data}

The analysis was carried out in banks, for which the number of observations exceed a period of five years and which are available on the websites of banks, Bankscope database, and the service of Thomson Reuters. The study was conducted in a period of 12 years, i.e. 2000-2012. The choice of research sample was dictated by the availability of data relating to individual commercial banks and the desire to take into account periods of market conditions and the financial crisis from 2008 to 2009. Characteristics of individual banking units is presented in Annedix I. The rate of return used in the calculations was calculated according to the model of Adrian and Brunnermeier (see Eq. 4).

\section{Estimates of the contribution of European banks to the instability of the banking sector - study}

Based on an earlier literature review and recommended methods for assessing systemic risk, CoVaR calculations were made for the banking sector (previously defined as the VaR of the financial system provided under crisis event of institution $i$ occurs). The aim of the study is to estimate the contribution of systemic risk by bank $i$ in country $j$ to the banking sector of country $j$. In addition, it will be created a ranking list of banks, which are a source of instability in the financial sector in developing countries of Europe. The study included commercial banks, only traded on the public market, which provided a market valuation of equity capital of the 40 largest commercial banks from 8 countries of developing Europe (Bulgaria, Latvia, Lithuania, Poland, Romania, Turkey, Ukraine, Hungary ${ }^{13}$.

The analysis was carried out in banks, for which the number of observations exceed a period of five years and be made available on the websites of banks, Bankscope database, and application of Thomson Reuters. The study was conducted in a period of 12 years, ie. 2000 to 2012. The choice of the survey sample was dictated by the availability of data relating to individual commercial banks and willingness to take into account periods of market trends of the financial crisis 2007-2009. 
Characteristics of individual banking units is presented in Appendix I. The rate of return used in the calculations was calculated according to the model of Adrian and Brunnermeier'a (see Eq. 4).

The study was conducted in two steps:

The first, CoVaR - the conditional value at risk for the banking sector was estimated, and the value of $\operatorname{VaR}$ for individual banks using the Algorithm (Eq. 2). Then the calculation of $\triangle$ CoVaR - the contribution of risk of the institution $i$ to the banking system. The change in the value under distress conditions of bank $i$ and the median value was specified as:

$$
\Delta \operatorname{CoVaR}_{q}^{\text {system }, i}=\operatorname{CoVaR}_{q}^{\text {system } \mid X^{i}=\operatorname{VaR} R_{q}^{i}}-\operatorname{CoVaR}_{q}^{\text {system } \mid X^{i}=\text { median }^{i}}
$$

The condition of bank $i$ failure were determined by $\operatorname{VaR}$ at confidence level $q=1 \%$. Comparison of individual risk values of $\mathrm{VaR}$ and changes in the value of $\triangle \mathrm{CoVaR}$ under distress conditions of bank $i$ (see Eq. 7) is used to estimate the difference between the valuation of systemic risk based on the contribution of all banking institutions to the total risk of the sector, and estimates based on traditional risk measures - VaR focus only on the risks of individual institutions. The results are illustrated in Figure 1.

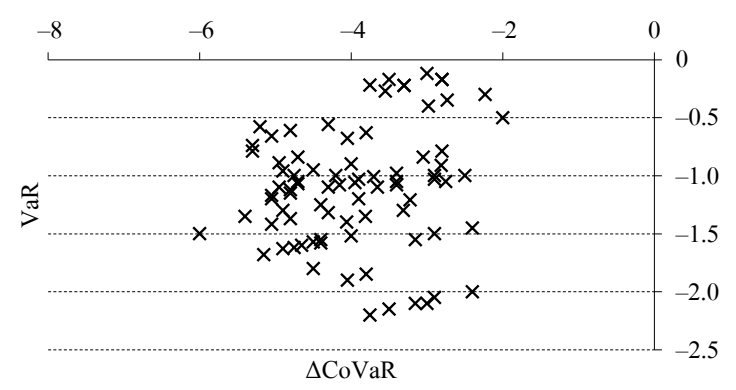

Fig. 1. The difference in the risk evaluation $V a R$ for the individual bank and the estimates of changes in the value of contingent $\triangle C O V a R$ for the banking sector

Source: own study.

There is no close relationship between the $\operatorname{VaR}$ and the estimates CoVaR, which confirmed earlier suspicions about the discrepancies in the estimates of these two measures and the advantage CoVaR. Therefore we consider different countries, the VaR and changes on CoVaR are nominal terms in local currencies. We change these calculation into Euro. The results show that the contribution of the institution to the instability of the banking sector measured by $\operatorname{CoVaR}$ is larger than the size $\mathrm{VaR}$ loss. Estimates $\triangle \mathrm{CoVaR}$ for estimated European banks 
ranged $[-1.9 ;-6.2]$, but the $\operatorname{VaR}$ values of $[-0.05 ;-2,7]$. It can therefore be concluded that the measure $\operatorname{VaR}$ for individual institutions does not bring complete information about the scale of the risk, hence the $\operatorname{VaR}$ values are lower than CoVaR. The size of $\triangle C o V a R$ shows the potential contribution of the financial institution (in the event of its insolvency) to the risk of the entire banking system.

The next step has been a detailed calculation of the impact of each of the analyzed financial institutions to systemic risk in the banking sector in each country. For this purpose the measurement of: $V a R_{q}^{\text {system }}$ for the banking sector of the country, on condition the occurrence of an incident on the entity $X^{i}$ :

$$
\operatorname{VaR}_{q}^{\text {system }} \mid X^{i}=X_{q}^{\text {system }, i}
$$

and the $\operatorname{VaR}$ for the following institutions $X^{t}$.

We used quantile regression model for $q=1 \%$, where $V a R$ for each bank $X^{i}$ is the independent variable, whereas the dependent variable is a conditional value $\operatorname{VaR}_{q}^{\text {system }} \mid X^{i}$ for the banking system. In Romania, Latvia and Hungary we could consider only 2 banks, because of data availability. This is not a good example for test equation, but we decided to show the results.

The quantile regression equation takes the following form:

$$
\begin{gathered}
X_{q}^{\text {system }, i}=\alpha_{q}^{i}+\beta_{q}^{i} X^{i} \\
\operatorname{CoVaR} R^{\text {system } \mid X^{i}=V a R_{q}^{i}}=\operatorname{VaR} R_{q}^{\text {system }} \mid \operatorname{VaR}{ }_{q}^{i}=\alpha_{q}^{i}+\beta_{q}^{i} \operatorname{VaR}_{q}^{i}
\end{gathered}
$$

The estimation results are presented in Table 1.

In the developing countries of Europe, the impact of risk measured by VaR of individual banks to the risk of the whole system is not large (see. Table 1). The size of the beta coefficient is mostly positive values adopted in the majority in the interval $[0 ; 0.5]$, which would indicate a low influence of listed commercial banks to the instability of the banking system in the event of a crisis. The group of the most influential includes: banks from Poland - Millenium and Bank BPH, from Hungary - FHB Jelzálogbank and OTP Bank, and Turkey - Albaraka Turk Katilim Bankasi. However, this situation is not optimistic if we take into account the significant share of foreign banks systemically important, which are present in the countries of Central and Eastern Europe. The effect of impact and the contagion systemic risk may be greater. The dominance of foreign banks in some Eastern and Central European countries is very important. However, this requires a broader analysis and research for the developed countries. 
Table 1. The impact of the VaR of the bank's risk on the whole national system.

The estimation results of regression (Eq. 9) for the developing countries of Europe

\begin{tabular}{|c|c|c|c|c|c|c|c|}
\hline No. & Bank(i)/Country & $\begin{array}{c}\beta \text { coefficient } \\
\text { (influence } \\
\text { of } \operatorname{VaR}(i) \\
\text { on CoVaR } \\
(\text { system)) }\end{array}$ & $\mathrm{p}$-value & No. & Bank(i)/Country & $\begin{array}{c}\beta \text { coefficient } \\
\text { (influence } \\
\text { of } \mathrm{VaR}(\mathrm{i}) \\
\text { on } \mathrm{CoVaR} \\
(\text { system) })\end{array}$ & p-value \\
\hline \multirow[t]{5}{*}{1.} & Bulgaria & & & \multirow[t]{16}{*}{6.} & Turkey & & \\
\hline & $\begin{array}{l}\text { Bulgarian-American Credit } \\
\text { Bank }\end{array}$ & 0.0996 & $* *$ & & Akbank & 0.06614 & $* * *$ \\
\hline & Central Cooperative Bank & 0.1376 & $* * *$ & & Albaraka Turk Katilim Bankasi & 0.95810 & $* *$ \\
\hline & Corporate Commercial Bank & 0.1163 & $*$ & & Alternatifbank & 0.87554 & $*$ \\
\hline & First Investment Bank & 0.0822 & $*$ & & Asya Katilim Bankasi & 0.37534 & $*$ \\
\hline \multirow[t]{9}{*}{2.} & Poland & & & & Denizbank & 0.11455 & \\
\hline & Bank PEKAO & 0.0366 & $*$ & & Finansbank & -0.00943 & $* *$ \\
\hline & BRE Bank & 0.0175 & $* *$ & & Sekerbank & 0.10883 & * \\
\hline & ING Bank & 0.6410 & $* * *$ & & Tekstil Bankasi & -0.00385 & \\
\hline & Millenium & 0.8478 & $* *$ & & Turk Ekonomi Bankasi & 0.0885 & $* *$ \\
\hline & PKO BP & 0.0136 & * & & Turkiye Garanti Bankasi & 0.08832 & $* * *$ \\
\hline & Bank Handlowy & 0.8034 & $* *$ & & Turkiye Halk Bankasi & 0.01031 & * \\
\hline & BOS Bank & 0.5541 & * & & Turkiye Is Bankasi & 0.01144 & $*$ \\
\hline & Bank BPH & 0.7822 & $*$ & & Turkiye Sinai Kalkinma Bankasi & 0.01996 & \\
\hline \multirow[t]{4}{*}{3.} & Lithuania & & & & Turkiye Vakiflar Bankasi & -0.00165 & * \\
\hline & Bankas Snoras & 0.0156 & $*$ & & Yapi ve Kredi Bankasi & 0.09665 & $* *$ \\
\hline & Siauliu Bankas & -0.0059 & $* *$ & \multirow[t]{8}{*}{7.} & Ukraine & & \\
\hline & Ukio Bankas & 0.0824 & $* *$ & & Bank Forum & 0.08065 & $* *$ \\
\hline \multirow[t]{3}{*}{4.} & Romania & & & & Raiffeisen Bank Aval & -0.00930 & $* *$ \\
\hline & Banca Comerciala Carpatica & 0.0478 & $* *$ & & Rodovid Bank & 0.02207 & $* *$ \\
\hline & Banca Transilvania & 0.2423 & * & & Ukrsotsbank & 0.06666 & $* *$ \\
\hline \multirow[t]{3}{*}{5.} & Hungary & & & & & & \\
\hline & FHB Jelzalogbank & 0.9744 & $* * *$ & & & & \\
\hline & OTP Bank & 0.8864 & $* *$ & & & & \\
\hline
\end{tabular}

$*, * *, * * *$ respectively denote the level of significance of $1 \%, 5 \%$ and $10 \%$. Characteristics of the banks participating in the survey in terms of size and risk taken are in Appedix I.

Source: own study.

\section{Conclusions}

The results of studies using the CoVaR indicator for measuring systemic risk confirmed earlier suspicions that the assessment of the banking system, closely based on the principles of valuation of individual financial institutions on the basis of the book value of assets, ignores interactions arising from systemic risks. The models proposed by Adrian and Brunnermeier ${ }^{14}$ based on the conditional $\mathrm{VaR}$, called by them the CoVaR have advantages in the form of: concentration on the contribution of individual institutions to the total systemic risk, while the 
traditional risk measures focus only on the risk level of a single institution. This is particularly important in view of the applicable prudential standards, showing significant deficiencies in the monitoring of risks in the system size. An important advantage of risk measures CoVaR is also its universal nature, which allows the verification of the mutual influence between institutions across the financial network. The study pointed to the importance of the impact of selected commercial banks to the instability of the banking system in the event of an emergency (eg. insolvency).

The regulator should be more inclined to monitor the CoVaR of banks because it can help identify before a crisis which institutions are more likely to suffer the most severe losses ex post. Our results hence tend to a practical use of the CoVaR for supervisory purposes.

\section{Appendix I}

Characteristics of the banks participating in the survey in terms of size and risk taken.

Calculations for selected developing countries in Europe

\begin{tabular}{|c|c|c|c|c|c|c|c|c|}
\hline Country/Bank & $\begin{array}{l}\text { No } \\
\text { obs. }\end{array}$ & $\begin{array}{l}\text { Equity book } \\
\text { value }\end{array}$ & $\begin{array}{l}\text { Asset book } \\
\text { value }\end{array}$ & $\begin{array}{c}\text { Market } \\
\text { capitalisation }\end{array}$ & $\begin{array}{c}\text { Value } \\
\text { of systemic } \\
\text { risk }\end{array}$ & Leverage & $\begin{array}{c}\text { Ratio } \\
\text { of systemic } \\
\text { risk } \\
\text { to equity }\end{array}$ & $\begin{array}{l}\text { Capital } \\
\text { ratio }\end{array}$ \\
\hline 1 & 2 & 3 & 4 & 5 & 6 & 7 & 8 & 9 \\
\hline \multicolumn{9}{|l|}{ Bulgaria } \\
\hline \multicolumn{9}{|l|}{ Bulgarian-American Credit } \\
\hline Bank & 1600 & 181.88 & 735.11 & 194.59 & -65.39 & 4.32 & -0.36 & 0.25 \\
\hline Central Cooperative Bank & 1856 & 228.8 & $1,700.80$ & 135.32 & -160.63 & 8.49 & -0.7 & 0.13 \\
\hline Corporate Commercial Bank & 1344 & 279.3 & $2,123.85$ & 450 & 80.65 & 9.12 & 0.29 & 0.13 \\
\hline First Investment Bank & 1344 & 402.9 & $4,270.80$ & 261.8 & -206.01 & 11.75 & -0.51 & 0.09 \\
\hline Total & & $1,092.88$ & $8,830.56$ & $1,041.71$ & -351.38 & 8.42 & -0.32 & 0.12 \\
\hline \multicolumn{9}{|l|}{ Czech republic } \\
\hline Komercni Banka & 1600 & $2,123.66$ & $23,160.57$ & $4,723.75$ & $2,609.25$ & 11.39 & 1.23 & 0.09 \\
\hline Total & & $2,123.66$ & $23,160.57$ & $4,723.75$ & $2,609.25$ & 11.39 & 1.23 & 0.09 \\
\hline \multicolumn{9}{|l|}{ Poland } \\
\hline Bank PEKAO & 1600 & $2,997.33$ & $23,483.30$ & $9,771.56$ & $5,066.85$ & 8.16 & 1.69 & 0.13 \\
\hline BRE Bank & 1600 & 897.03 & $13,391.28$ & $2,627.41$ & 383.74 & 16.55 & 0.43 & 0.07 \\
\hline ING Bank & 1600 & 974.02 & $11,841.53$ & $2,406.85$ & 313.96 & 11.55 & 0.32 & 0.08 \\
\hline Millenium & 1600 & 638.87 & $7,772.16$ & $1,395.08$ & 71.58 & 11.68 & 0.11 & 0.08 \\
\hline PKO BP & 1600 & $3,615.12$ & $32,329.99$ & $11,464.97$ & $6,025.09$ & 9.62 & 1.67 & 0.11 \\
\hline Bank HANDLOWY & 1600 & $1,466.79$ & $9,424.69$ & $2,613.19$ & 555.73 & 6.27 & 0.38 & 0.16 \\
\hline BOS Bank & 1600 & 207.08 & $2,479.23$ & 301.27 & -74.45 & 11.88 & -0.36 & 0.08 \\
\hline Bank BPH & 1600 & $1,182.94$ & $10,609.36$ & 702.41 & $-1,579.67$ & 8.81 & -1.34 & 0.11 \\
\hline Total & & $11,979.18$ & $111,331.55$ & $31,282.75$ & $2,690.71$ & 10.18 & 0.22 & 0.11 \\
\hline \multicolumn{9}{|l|}{ Latvia } \\
\hline Latvijas Krajbanka & 1600 & 36.4 & 513.9 & 32.78 & -25.28 & 14.4 & -0.69 & 0.07 \\
\hline Total & & 36.4 & 513.9 & 32.78 & -25.28 & 14.4 & -0.69 & 0.07 \\
\hline
\end{tabular}




\begin{tabular}{|c|c|c|c|c|c|c|c|c|}
\hline 1 & 2 & 3 & 4 & 5 & 6 & 7 & 8 & 9 \\
\hline \multicolumn{9}{|l|}{ Lithuania } \\
\hline Bankas Snoras & 960 & 552 & $8,997.00$ & 440.18 & -380.09 & 16.6 & -0.69 & 0.06 \\
\hline Siauliu Bankas & 1920 & 257.25 & $2,076.70$ & 214.92 & -59.04 & 9.04 & -0.23 & 0.12 \\
\hline Ukio Bankas & 1984 & 429 & $4,225.00$ & 297.71 & -174.89 & 9.72 & -0.41 & 0.1 \\
\hline Total & & $1,238.25$ & $15,298.70$ & 952.81 & -614.02 & 11.79 & -0.5 & 0.08 \\
\hline \multicolumn{9}{|l|}{ Romania } \\
\hline Banca Comerciala Carpatica & 1856 & 221.9 & $2,309.50$ & 366.28 & -205.43 & 10.21 & -0.93 & 0.1 \\
\hline Banca Transilvania & 2112 & $1,422.00$ & $15,807.00$ & $2,026.44$ & 512.96 & 10.82 & 0.36 & 0.09 \\
\hline Total & & $1,643.90$ & $18,116.50$ & $2,392.72$ & 307.53 & 10.51 & 0.19 & 0.09 \\
\hline \multicolumn{9}{|l|}{ Turkey } \\
\hline Akbank & 3456 & $6,217.50$ & $52,677.00$ & $12,565.45$ & -834.64 & 7.1 & -0.13 & 0.12 \\
\hline \multicolumn{9}{|l|}{ Albaraka Turk Katilim } \\
\hline Bankasi & 1344 & 711 & $6,415.00$ & $1,141.87$ & -251.88 & 9.02 & -0.35 & 0.11 \\
\hline Alternatifbank & 3136 & 157.8 & $1,765.20$ & 318 & -211.97 & 10.65 & -1.34 & 0.09 \\
\hline Asya Katilim Bankasi & 1600 & $1,545.00$ & $9,876.00$ & $1,746.00$ & -441.12 & 7.25 & -0.29 & 0.16 \\
\hline Denizbank & 1984 & $2,261.00$ & $22,576.00$ & $2,950.33$ & -885.29 & 10.14 & -0.39 & 0.1 \\
\hline Finansbank & 3712 & $1,279.50$ & $14,867.50$ & $2,058.78$ & $1,302.60$ & 9.09 & 1.02 & 0.09 \\
\hline Sekerbank & 3200 & 324 & $3,543.00$ & 570.53 & -603.98 & 10.75 & -1.86 & 0.09 \\
\hline Tekstil Bankasi & 3456 & 165.7 & $1,792.25$ & 193.2 & -237.33 & 8.03 & -1.43 & 0.09 \\
\hline Turk Ekonomi Bankasi & 2176 & $1,070.00$ & $15,306.50$ & $1,337.93$ & $-1,014.64$ & 12.09 & -0.95 & 0.07 \\
\hline Turkiye Garanti Bankasi & 3200 & $4,146.00$ & $48,510.50$ & $8,828.85$ & $-2,708.46$ & 9.71 & -0.65 & 0.09 \\
\hline Turkiye Halk Bankasi & 1344 & $5,770.00$ & $60,783.00$ & $12,195.63$ & 738.86 & 10.53 & 0.13 & 0.09 \\
\hline Turkiye Is Bankasi & 3712 & $7,928.50$ & $50,475.00$ & $9,812.60$ & $-6,926.15$ & 7.48 & -0.87 & 0.16 \\
\hline \multicolumn{9}{|l|}{ Turkiye Sinai Kalkinma } \\
\hline Bankasi & 3200 & 548 & $3,564.50$ & 440.95 & -450.2 & 6.99 & -0.82 & 0.15 \\
\hline Turkiye Vakiflar Bankasi & 1728 & $6,064.00$ & $58,503.00$ & $7,976.53$ & $-2,894.54$ & 9.56 & -0.48 & 0.1 \\
\hline Yapi ve Kredi Bankasi & 3712 & $3,589.50$ & $25,843.00$ & $3,987.98$ & $-4,077.67$ & 8.66 & -1.14 & 0.14 \\
\hline Total & & $41,777.50$ & $376,497.45$ & $66,124.65$ & $-19,496.40$ & 9.14 & -0.47 & 0.11 \\
\hline \multicolumn{9}{|l|}{ Ukraine } \\
\hline Bank Forum & 1088 & $1,591.59$ & $15,426.94$ & $1,512.98$ & $-1,244.76$ & 8.62 & -0.78 & 0.1 \\
\hline Raiffeisen Bank Aval & 640 & $6,351.30$ & $53,181.70$ & $8,718.53$ & $-3,558.84$ & 8.45 & -0.56 & 0.12 \\
\hline Rodovid Bank & 1408 & $1,862.32$ & $10,179.00$ & $1,092.25$ & $-3,597.90$ & 7.7 & -1.93 & 0.18 \\
\hline Ukrsotsbank & 1472 & $4,494.76$ & $35,389.93$ & $6,405.20$ & $-1,376.53$ & 8.81 & -0.31 & 0.13 \\
\hline Total & & $14,299.97$ & $114,177.58$ & $17,728.96$ & $-9,778.04$ & 8.39 & -0.68 & 0.13 \\
\hline \multicolumn{9}{|l|}{ Hungary } \\
\hline FHB Jelzalogbank & 2240 & $36,061.00$ & $630,738.00$ & $68,429.78$ & $-6,191.39$ & 18.14 & -0.17 & 0.06 \\
\hline OTP Bank & 2944 & $717,759.50$ & $6,636,079.50$ & $1,349,272.30$ & $134,015.22$ & 9.51 & 0.19 & 0.11 \\
\hline Total & & $753,820.50$ & $7,266,817.50$ & $1,417,702.08$ & $127,823.83$ & 13.83 & 0.17 & 0.1 \\
\hline
\end{tabular}

Legend: (1) leverage ratio = volume of assets/equity of the bank, (2) the value of systemic risk = market value of assets, calculated on the basis of option pricing model - the book value of assets, (3) the systemic risk to equity = risk value system/equity of the bank, (4) capital ratio = equity/book value of assets.

Source: own study. 


\section{Notes}

1 Tasche (2000).

2 Brownlees, Engle (2010).

3 Acharya et al. (2010).

4 Kupiec (2002).

5 Jorion (2006).

6 Brunnermeier et al. (2009).

7 Brady (1988).

8 Rubin et al. (1999).

9 Brunnermeier (2009).

10 Adrian, Shin (2010).

11 Adrian, Brunnermeier (2011).

12 Ibidem.

${ }^{13}$ The study also included Turkish banks, due to Turkey's aspirations to join the European Union, a significant share of the banking sector in the sample and the location of banks in Istanbul.

${ }^{14}$ Ibidem.

\section{References}

Adrian, T. \& Shin, H. (2010). The Changing Nature of Financial Intermediation and the Financial Crisis of 2007-2009. Annual Review of Economics, (2), 603-618.

Adrian, T. \& Brunnermeier, M.K. (2011). CoVaR. Federal Reserve Bank of New York.

Acharya, V., Pedersen, L., Philippon, T. \& Richardson, M. (2010). Measuring systemic risk. Technical report, Department of Finance, NYU.

Brady, N.F. (1988). Report of the Presidential Task Force on Market Mechanisms. U.S. Government Printing Office.

Brownlees, C. \& Engle, R. (2010). Volatility, Correlation and Tails for Systemic Risk Measurement. Working Paper Series, Department of Finance, NYU.

Brunnermeier, M.K., Crocket, A., Goodhart, C., Perssaud, A. \& Shin, H. (2009). The Fundamental Principles of Financial Regulation. 11th Geneva Report on the World Economy.

Brunnermeier, M.K. (2009). Deciphering the Liquidity and Credit Crunch 2007-2008. Journal of Economic Perspectives, 23 (1), 77-100.

Jorion, P. (2006). Value at Risk. McGraw-Hill, 3rd edn.

Kupiec, P. (2002). Stress-testing in a Value at Risk Framework, Risk Management: Value at Risk and Beyond.

Rubin, R.E., Greenspan, A., Levitt, A. \& Born, B. (1999). Hedge Funds, Leverage, and the Lessons of Long-Term Capital Management. Report of The President's Working Group on Financial Markets.

Tasche, D. (2000). Risk Contributions and Performance Measurement. DP University of Munich. 